\title{
Dating of zircon and monazite from diamondiferous quartzofeldspathic rocks of the Saxonian Erzgebirge - hints at burial and exhumation velocities
}

\author{
H. J. Massonne ${ }^{1 *}$, A. Kennedy ${ }^{2}$, L. Nasdala ${ }^{3}$ and T. Theye ${ }^{1}$ \\ ${ }^{1}$ Institut für Mineralogie und Kristallchemie, Universität Stuttgart, Azenbergstr. 18, D-70174 Stuttgart, Germany \\ 2 Department of Applied Physics, Curtin University of Technology, Kent St. Bentley WA, 6102, Australia \\ ${ }^{3}$ Institut für Mineralogie und Kristallographie, Universität Wien, Althanstr. 14, A-1090 Vienna, Austria
}

[Received 23 March 2007; Accepted 4 December 2007]

\section{ABSTRACT}

In order to better understand the formation and evolution processes of ultrahigh pressure (UHP) felsic rocks, we determined the ages of various domains of zircon and monazite crystals from the diamondiferous quartzofeldspathic rocks of the Saxonian Erzgebirge. According to cathodoluminescence imagery and $\mathrm{Th} / \mathrm{U}$ ratios, three zircon zones were distinguished. Each zone was dated using several spot analyses from a sensitive high-resolution ion microprobe (SHRIMP) analysing $\mathrm{Pb}, \mathrm{U}$ and Th isotopes. The results were: (1) core zone - 21 analyses: Th/U $\leqslant 0.023$ and $337.0 \pm 2.7 \mathrm{Ma}(2 \sigma$, combined ${ }^{206} \mathrm{~Pb} /{ }^{238} \mathrm{U}-{ }^{207} \mathrm{~Pb} /{ }^{235} \mathrm{U}$ age); (2) diamond-bearing intermediate zone -23 analyses: Th/U $\geqslant 0.037$ and $336.8 \pm 2.8 \mathrm{Ma}$; and (3) rim zone -12 analyses: $\mathrm{Th} / \mathrm{U}=0.015-0.038$ (plus one analysis of $0.164)$ and $330.2 \pm 5.8 \mathrm{Ma}$. The obtained $\mathrm{U}-\mathrm{Pb}$ ages are virtually concordant. Furthermore, two oscillatory zoned zircon cores $(\mathrm{Th} / \mathrm{U} \geqslant 0.8)$ yielded ( concordant) ages of $\sim 400 \mathrm{Ma}$. Six SHRIMP analyses of monazites gave an age of $332.4 \pm 2.1 \mathrm{Ma}$. In addition, $\mathrm{Pb}$, Th and $\mathrm{U}$ contents in monazite were analysed with an electron microprobe (EMP). A mean age of $324.7 \pm 8.0(2 \sigma)$ Ma was acquired from 113 analyses.

By combining the defined ages with previously published $P$ - $T$ conditions, minimum velocities for burial and exhumation were estimated. In addition, we present a likely geodynamic scenario involving age data from the literature as well as this study: starting 340 million years ago, gneisses at the base of a thickened continental crust $\left(\sim 1.8 \mathrm{GPa}, 650^{\circ} \mathrm{C}\right)$ were transported to depths of at least $130 \mathrm{~km}$, possibly as deep as $250 \mathrm{~km}$. They were heated $\left(>1050^{\circ} \mathrm{C}\right)$, partially melted and as a result began to rise quickly. The burial and following ascent back to a depth of $50 \mathrm{~km}$, where zircon rims and monazite formed, took only a few million years and perhaps significantly less.

KeYwords: zircon, monazite, geochronology, SHRIMP, EMP, Saxonian Erzgebirge, Variscan, ultrahigh pressure metamorphism, exhumation.

\section{Introduction}

Ultrahigh PRESSURE (UHP) rocks rich in $\mathrm{SiO}_{2}$ (>62 wt.\%) form during continent-continent collision. Such rocks have been found mainly by recognizing the indicator minerals coesite and diamond in various, mostly Phanerozoic orogens

\footnotetext{
* E-mail: h-j.massonne@mineralogie.uni-stuttgart.de DOI: $10.1180 /$ minmag.2007.071.4.371
}

such as the Alpine chain, the Norwegian Caledonides and the Qinling-Dabie-Sulu belt in China (see summary in Chopin, 2003). Among these UHP regions there are only two, the Kokchetav Massif in northern Kazakhstan and the Saxonian Erzgebirge in central Europe, where diamondiferous quartzofeldspathic rocks were reported in which UHP phase relations could be detected due to the appearance of abundant microdiamonds (Shatsky et al., 1995; Massonne, 2003). These microdiamonds also occur as 
inclusions in zircon, thus allowing researchers to link the age of zircon formation with the UHP stage using advanced dating techniques. This important goal was first achieved for diamondiferous rocks from the Kokchetav Massif by Claoue-Long et al. (1991) who determined an age of $530 \pm 7(2 \sigma)$ Ma by sensitive high-resolution ion microprobe (SHRIMP) measurements. Hermann et al. (2001) also reported SHRIMP data on diamond-bearing zircon (domain 2 according to these authors) leading to the following interpretation: the UHP event probably occurred at a depth of $\sim 200 \mathrm{~km}$ (Ota et al., 2000; Massonne, 2003), at $527 \pm 5 \mathrm{Ma}$. A younger zircon domain (domain 3 according to Hermann et al., 2001) formed after significant exhumation and this domain yielded ages of $528 \pm 8 \mathrm{Ma}$. Hermann et al. (2001) estimated a minimum exhumation rate of $1.8 \mathrm{~cm} /$ year from this data. However, a much greater exhumation rate is also possible based on the above information. A major problem is related to the burial event of the diamondiferous rocks from the Kokchetav Massif. Katayama et al. (2000) reported graphite inclusions in the core of zircon grains which enclose abundant microdiamonds (in domain 2). These authors concluded from this observation that a prograde event related to the burial of the rocks can be conserved in portions of the diamond-bearing zircons from quartzofeldspathic rocks of the Kokchetav Massif. Hermann et al. (2001) confirmed this idea by identifying chlorite and plagioclase as inclusions in the core domain 1. This domain yielded an age of $535 \pm 9 \mathrm{Ma}$ which, however, was not used to estimate a minimum burial rate. Such a pre-UHP metamorphism zircon domain was also detected in the diamondiferous quartzofeldspathic rocks (saidenbachites) from the Saxonian Erzgebirge. Massonne and Nasdala (2003) found inclusions of garnet and jadeitic pyroxene belonging to an assemblage formed at a pressure $(P)$ of $\sim 1.8 \mathrm{GPa}$ and a temperature $(T)$ of $650^{\circ} \mathrm{C}$ in the core of diamond-bearing zircons. This core is characterized by low cathodoluminescence (CL) under the beam of an electron microprobe (EMP). After the formation of this mineral assemblage, the rocks were buried to depths corresponding to pressures of at least $5 \mathrm{GPa}$ and possibly as high as $8 \mathrm{GPa}$ (Massonne, 2003). At these depths $(\geqslant 150 \mathrm{~km}$ and possibly up to $240 \mathrm{~km}$ ), although more likely during exhumation (Massonne, 2003), small diamonds (Fig. 1) were enclosed by the intermediate zircon zone growing around the garnetjadeite bearing core. This zone has brighter $\mathrm{CL}$ than that of the zircon cores. The outermost zircon zone probably formed during the equilibration stage of the rock matrix, which comprises potassic white mica, plagioclase, quartz, garnet and possibly kyanite (this phase was at least present under UHP conditions). This zone shows the brightest CL of the investigated zircons (Massonne and Nasdala, 2003). The matrixforming event was related to $P-T$ conditions between $1.5-1.8 \mathrm{GPa}$ and $700-750^{\circ} \mathrm{C}$. Due to the clearly developed composite patterns of the zircons consisting of successively formed distinct domains, we aimed at dating these different zircon zones within samples of the diamondiferous rocks from the Saxonian Erzgebirge. An additional aim was to better understand the processes of burial and exhumation to and from great depths in the Earth, respectively. For this geochronological investigation we used the SHRIMP II at Curtin University in Perth, Australia. Preliminary geochronological results were reported by Massonne et al. (2001). In addition, monazites from the same rocks were dated using an EMP (as well as the SHRIMP II) technique.

\section{Geological setting, rock samples and mineral concentrate specimens}

As a result of the collision of Gondwana and Laurussia in late Palaeozoic times, UHP rocks occur in various portions of the Bohemian Massif (for summary see Massonne and O'Brien, 2003); an extended area of exposed basement located at the north-eastern edge of the Variscan orogen.

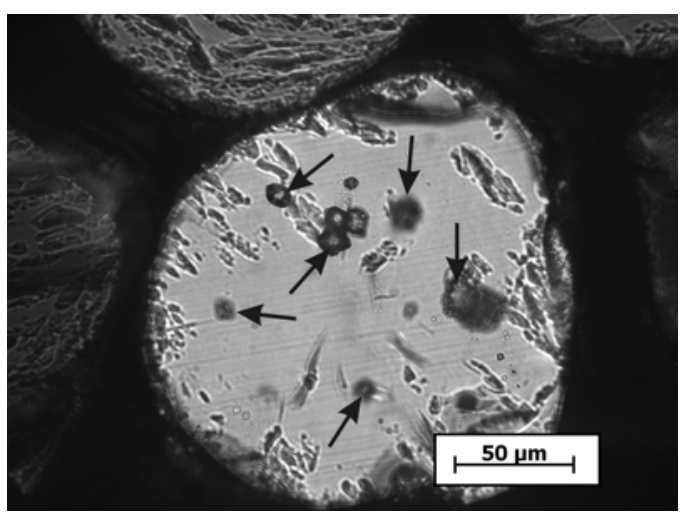

FIG. 1. Photomicrograph of zircon, separated from a saidenbachite, containing several microdiamonds (see arrows) below and above the focal plane. 
The Saxonian Erzgebirge (Fig. 2) is an ovalshaped antiformal structure extending about $80 \mathrm{~km}$ in ESE-WNW direction. It is situated in the north-western Bohemian Massif and part of the Saxothuringian zone, which is a collage mainly consisting of crystalline basement complexes, anchimetamorphic early Palaeozoic basin fillings and late Palaeozoic post-orogenic granitoid bodies. The Saxothuringian zone is bounded by the Variscan orogenic structure of the Mid-German crystalline rise to the north and the Moldanubian zone, dominated by high-grade crystalline rocks and Carboniferous granitoids as part of the Bohemian Massif, to the south. The Saxonian Erzgebirge is composed of several major units, with several further subdivision schemes, although here we use that of Willner et al. (2000), who subdivided the Erzgebirge into the following zones: (1) Phyllite Unit (PU), (2) Grey Gneiss Unit (GGU), (3) Mica-schistEclogite Unit (MEU) and (4) Gneiss-Eclogite Unit (GEU). These likley form a nappe stack with the GGU at the bottom and the PU on top. Highpressure (HP) rocks occur exclusively in the MEU and GEU. In the latter unit, UHP rocks were detected in the central Erzgebirge such as coesitebearing eclogite (Massonne, 2001) and garnet peridotite (see Massonne and Neuser, 2005). These rocks form lensoid bodies embedded in migmatitic gneisses which experienced metamorphic $P$ - $T$ conditions as high as $20 \mathrm{kbar}$ and $800^{\circ} \mathrm{C}$ (Willner et al., 1997). Zircons in these HP gneisses were previously dated with ages of $340.5 \pm 1.1(2 \sigma), 341.3 \pm 1.1$, and $341.6 \pm 1.1 \mathrm{Ma}$ (Kröner and Willner, 1998: $\mathrm{Pb}-\mathrm{Pb}$ evaporation). Tichomirowa et al. (2005) also reported zircons from GEU gneisses with U-Pb ages of $340 \mathrm{Ma}$. However, analyses of zircon cores from orthogneisses of the GEU resulted in protolith ages of 470-500 Ma. These U-Pb ages, determined on long prismatic zircons, were also found for orthogneisses of the GGU of the eastern Erzgebirge by Tichomirowa et al. (2001). In addition, these authors reported Cambrian protolith ages for other orthogneisses and Neoproterozoic to Archean ages for zircons in metasediments of the GGU. Uranium/lead ages of $\sim 340 \mathrm{Ma}$ were also found in zircons from HP rocks of other crystalline massifs of the Bohemian Massif (see summary in Massonne and O'Brien,

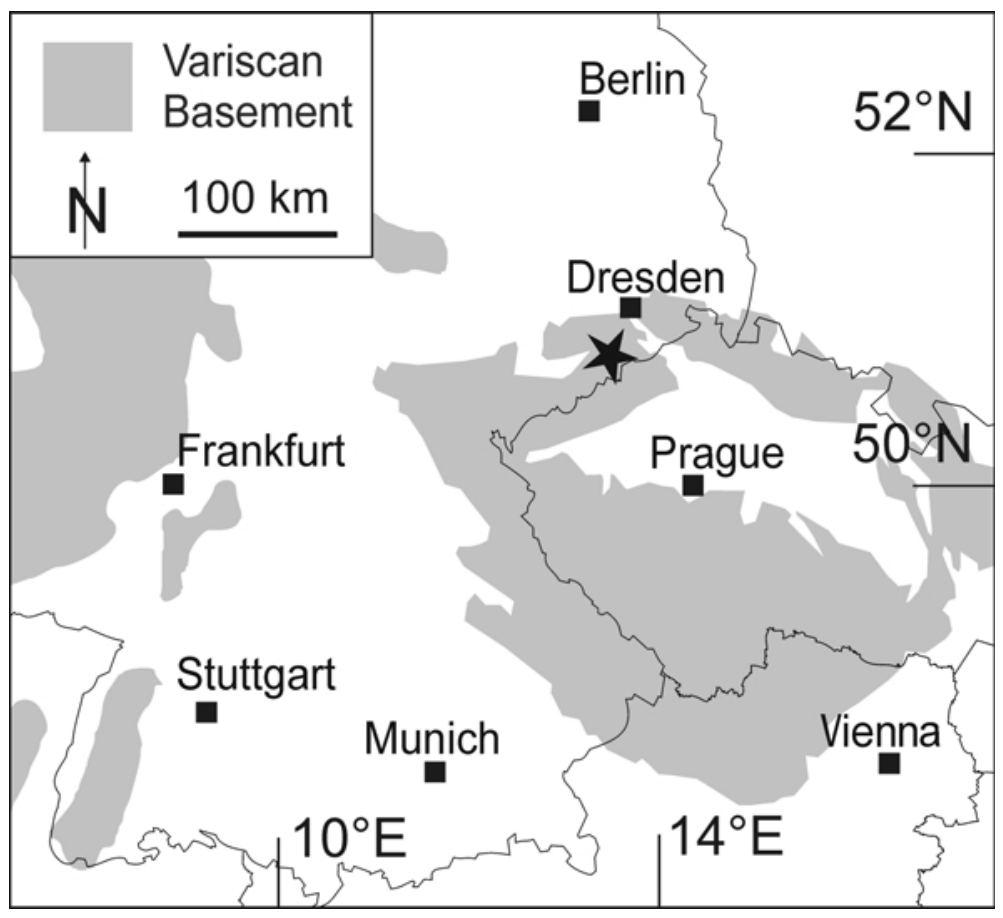

FIG. 2. Distribution of exposed Variscan basement in central Europe. Star shows the position of the UHP area in the Erzgebirge (modified from Stöckhert et al., 2001). 


\section{H. J. MASSONNE ET AL.}

2003), e.g. Romer and Rötzler (2001) reported an age of $341.5 \pm 0.8 \mathrm{Ma}$ for the high temperature metamorphism of HP granulites from the Saxonian Granulitgebirge (35 km north-west of the Saidenbach reservoir).

Diamondiferous quartzofeldspathic rocks (saidenbachites) occur exclusively in the GEU as lenses which can extend for several hundreds of metres, such as those at the Saidenbach reservoir near the village of Forchheim (for a detailed map see Massonne, 2001). The association of the various UHP rock types is uncertain, because other UHP rock lenses comprising eclogite and peridotite are separate from the


FIG. 3. Cathodoluminescence images of zircon grains (fraction $125-250 \mu \mathrm{m}$ ), separated from diamondiferous quartzofeldspathic rock sample St6100. (a) Overview. White arrows show relatively extended zircon rims with light CL. Less than one half of the zircons show cores typically with (portions of) minor CL. Black spots in the zircons are due to mineral inclusions among which microdiamonds dominate. (b) Enlarged area of the zircon population. Arrows show zircon cores which are typically corroded. This is shown best in the middle zircon (white arrow) where relatively large microdiamonds (black spots) appear. In addition, the diamond-bearing intermediate zone in zircons often shows a relatively homogeneous CL. (c) Zircon with core (tentatively outlined by the black line) showing rare alternating zones typical of magmatic zircons. 
saidenbachite bodies. In contrast to the surrounding gneisses, the saidenbachites show typical bulk rock compositions of clastic sediments (Düffels and Massonne, 2001). As a result Massonne (2003) concluded the protoliths of the saidenbachites were greywackes. Zircon and monazite are omnipresent accessory phases in the saidenbachites. In almost every thin section $\left(\sim 2 \times 4 \mathrm{~cm}^{2}\right)$ of this rock type, several grains of these minerals were found. They occur as generally well rounded grains up to several hundred of micrometres in length. Microdiamonds are ubiquitous in zircon (Fig. 1) which has the greatest diamond concentration relative to other host minerals: garnet, kyanite and very rarely rutile (Nasdala and Massonne, 2000). In contrast, only one microdiamond has currently been detected in a monazite (core). EMP-related $\mathrm{CL}$ and back-scattered electron (BSE) imagery of zircon and monazite (Figs. 3-5) in polished thin sections of various saidenbachite samples has identified a complex zonation pattern for zircon (see above). Monazite grains are either unzoned or occasionally show two zones. As the characteristics of the zircon zonation were found in all saidenbachites investigated with the EMP, we focussed our analytical work on mineral concentrates from two samples. These samples,


FIG. 4. Cathodoluminescence images of selected zircon grains from samples E97-2 and St6100. Scale bars represent $50 \mu \mathrm{m}$. The open ovals refer to ablation pits produced by SHRIMP analysis (see Table 1). The zircon in the centre has a magmatic core (analysis St6100-15) inside a metamorphic mantle which is surrounded by a wide intermediate zone also analysed by SHRIMP (St6100-23). Note that analysis E972-6 (top right hand side) had to be discarded because of an operational error. 
E97-2 and St6100, also studied petrologically by Massonne and Nasdala (2003), were collected from blocks occurring virtually at the same spot in a diamondiferous quartzofeldspathic rock lens $1.5 \mathrm{~km} \mathrm{NW}$ of the village of Forchheim.

The mineral concentrates were obtained after crushing and sieving of the rock samples using standard procedures with a FRANTZ isodynamic magnetic separator and heavy liquids (polywolframate solution). Finally, purified concentrates of zircon and monazite $(>95 \%)$ separated into $125-250$ and $250-500 \mu \mathrm{m}$ fractions were gained by hand-picking. Monazite grains could be easily distinguished from zircons by their yellow to yellow-green colour. In contrast, most zircon grains are colourless to slightly reddish and clear so that microdiamond inclusions can easily be seen under a stereo binocular microscope as little black spots in the zircons. For SHRIMP analysis, $\sim 1000$ grains of the $125-250 \mu \mathrm{m}$ fraction of sample St6100 and fragments of the CZ3 standard zircon (Kennedy, 2000) were embedded in araldite filling boreholes in a $1 \mathrm{~mm}$ thick circular ceramic plate $(\phi 2.4 \mathrm{~cm})$. This plate was abraded and finally hand-polished so that the zircon grains were cut approximately through the middle. Similarly, two other ceramic plates, filled with zircons from the $125-250 \mu \mathrm{m}$ and $250-500 \mu \mathrm{m}$


FIG. 5. (a) Secondary electron image of a monazite grain from a thin section of sample E97-2 (striations around a microdiamond (black) in the centre of the grain are a result of the polishing technique - see Massonne et al., 1998). (b) Backscattered electron image of a different monazite grain from the same sample. Both images were taken using a CAMECA SX 100 EMP. Scale bars represent $50 \mu \mathrm{m}$. $(c, d)$ Chemical profiles following the track shown by circles in the grains of (a) and (b). The concentrations of $\mathrm{Ca}$, Th and $\mathrm{U}$ are given in terms of cations per formula unit (c.f.u.). 
fractions of sample E97-2, were prepared. Eleven monazites of sample E97-2 with an average size of $300 \mu \mathrm{m}$ were embedded in araldite in a fourth ceramic plate mount for SHRIMP analyses. Other monazites from thin sections of E97-2 were dated using the EMP. For this purpose, the thin sections were polished by hand with silicon carbide.

\section{Analytical techniques SHRIMP}

Before analysing with a SHRIMP II, all zircon and monazite grains in the aforementioned ceramic discs were inspected with a CL and BSE detector on a Cameca SX100 electron microprobe. The obtained images were stored digitally and used to pre-select appropriate (e.g. homogeneous) areas in the core, intermediate, and outer (rim) zones of zircon, wide enough for the secondary ion beam of the SHRIMP ablating spots $(25 \mu \mathrm{m}$ diameter $)$. The separated and embedded monazites for SHRIMP analysis were homogeneous in BSE and CL images. Zircons in the gold coated ceramic discs were analysed in the SHRIMP II (De Laeter and Kennedy, 1998) using the following procedures and conditions. Due to the relatively low $\mathrm{U}$ and $\mathrm{Th}$ contents, the analysis time for the ${ }^{206} \mathrm{~Pb}^{+}$and ${ }^{207} \mathrm{~Pb}^{+}$peaks was extended to 20 and 40 s, respectively. Seven cycles of the nine mass positions (additionally ${ }^{196} \mathrm{Zr}_{2} \mathrm{O}^{+}$, ${ }^{204} \mathrm{~Pb}^{+}$, background, ${ }^{208} \mathrm{~Pb}^{+},{ }^{232} \mathrm{Th}^{+},{ }^{238} \mathrm{U}^{+}$and ${ }^{254} \mathrm{UO}^{+}$) were completed in each analysis. Measurements of the CZ3 standard were undertaken throughout the 24 hours of analytical time, interspersed with the analysis of the unknowns. Off-line data processing used the correction procedures of Compston et al. (1984), as reported by Breitkreuz and Kennedy (1999). For monazites seven cycles of the following measurement intervals and peaks were recorded: $3 \mathrm{~s}$ for ${ }^{202} \mathrm{LaPO}_{2}^{+}$and ${ }^{203} \mathrm{CePO}_{2}^{+} ; 10 \mathrm{~s}$ for ${ }^{204} \mathrm{~Pb}^{+},{ }^{206} \mathrm{~Pb}^{+}$ and background; $20 \mathrm{~s}$ for ${ }^{207} \mathrm{~Pb}^{+}$; $2 \mathrm{~s}$ for ${ }^{208} \mathrm{~Pb}^{+}$, ${ }^{232} \mathrm{Th}^{+},{ }^{254} \mathrm{UO}^{+},{ }^{264} \mathrm{ThO}_{2}^{+}$, and ${ }^{270} \mathrm{UO}_{2}^{+}$. Age calculations were performed using the Isoplot 2.06 software of Ludwig (1999) with IUGS recommended constants (Steiger and Jäger, 1977).

\section{$E M P$}

For the EMP dating of the Erzgebirge monazites, we used a Cameca SX100 equipped with five wavelength dispersive (WDS) spectrometers. The measurements were achieved on thin sections coated with a $30 \mathrm{~nm}$ carbon layer. At first, 82 analyses were performed with a $15 \mathrm{kV}$ acceleration voltage and $30 \mathrm{nA}$ beam current. To reduce the resulting age uncertainties, 40 additional analyses were undertaken using a larger beam current of $200 \mathrm{nA}$. For these measurements, recommendations by Pyle et al. (2005) and Jercinovic and Williams (2005) were been considered. For each full analysis of monazite, the most common rareearth elements (REEs) and $\mathrm{Pb}, \mathrm{U}, \mathrm{Th}, \mathrm{P}, \mathrm{Ca}, \mathrm{Si}$ and $\mathrm{Y}$ were measured using the following emission lines and standards: $\mathrm{Ca}-K \alpha$ (diopside), U- $M \beta$ (U-bearing glass), Th- $M \alpha$ (Th-bearing glass), $\mathrm{Pb}-M \beta$ (PbTe) for the $30 \mathrm{nA}$ measurements, $\mathrm{Pb}-\mathrm{M \alpha}(\mathrm{PbTe})$ for the $200 \mathrm{nA}$ measurements, Ce$L \alpha$ (30 nA: synthetic REE-rich glass delivered by P\&H Developments, England, 200 nA: Ce-phosphate), La- $L \alpha$ (30 nA: synthetic REE-rich glass,

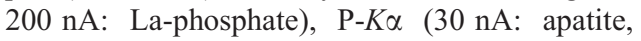
200 nA: La-phosphate), Y- $L \alpha$ (30 nA: synthetic $R E E$-rich glass, $200 \mathrm{nA}$ : Y-phosphate), $\operatorname{Pr}-L \beta$ (30 nA: synthetic REE-rich glass, $200 \mathrm{nA}$ : Prphosphate), Nd- $L \alpha$ (30 nA: synthetic REE-rich glass, $200 \mathrm{nA}$ : Nd-phosphate), Sm- $L \alpha$ (30 nA: synthetic $R E E$-rich glass, $200 \mathrm{nA}: \mathrm{Sm}$-phosphate), Gd- $L \beta$ (30 nA: synthetic REE-rich glass, $200 \mathrm{nA}$ : Gd-phosphate), Si-K $\alpha$ (30 nA: orthoclase, $200 \mathrm{nA}$ : diopside). Additional elements such as As and $\mathrm{Sr}$ were not analysed they could not be detected in the initial WDS scans prior to full analysis. Oxygen was not measured but calculated by stoichiometry. For the background measurements of the REEs, we followed the recommendations of Reed and Buckley (1998). The counting times on both peak and background for the critical elements $\mathrm{Pb}, \mathrm{U}$ and Th were: $300 \mathrm{~s}$ for $\mathrm{Pb}-M \beta, 150 \mathrm{~s}$ for $\mathrm{U}-M \beta$ and Th- $M \alpha$ for the $30 \mathrm{nA}$ measurements and $500 \mathrm{~s}$ for $\mathrm{Pb}-M \alpha, 260 \mathrm{~s}$ for $\mathrm{U}-M \beta, 140 \mathrm{~s}$ for Th- $M \alpha$ at $200 \mathrm{nA}, 600 \mathrm{~s}$ for $\mathrm{Pb}-M \beta, 300 \mathrm{~s}$ for $\mathrm{U}-M \beta$ and Th- $M \alpha(30 \mathrm{nA}), 260 \mathrm{~s}$ for U-M $(200 \mathrm{nA})$ and $140 \mathrm{~s}$ for Th-M $\alpha(200 \mathrm{nA})$. We measured $\mathrm{U}$ and Th with a normal-sized PET (polyethylene) spectrometer crystal, while Lead was analysed with a large PET crystal. Similar to Scherrer et al. (2000), a (small) correction of the U-M $\beta$ peak was applied due to the contribution from the Th- $M \gamma$ line. For the measurements at $200 \mathrm{nA}$, a correction of $\mathrm{Pb}-\mathrm{M \alpha}$ for interferences with $\mathrm{Th}$ and $\mathrm{Y}$ lines was undertaken. The counting times for all other elements ranged between $200 \mathrm{~s}$ and $20 \mathrm{~s}$ for both peak and background. All REEs were measured with LIF (lithium fluoride) spectrometer crystals.

Using the above settings and conditions, we analysed fragments of the gem-quality pegmatitic monazite from the Itambe pegmatite district, 




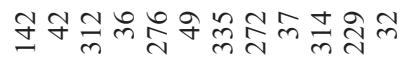

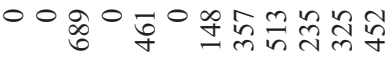

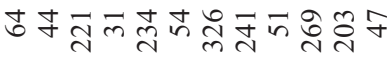

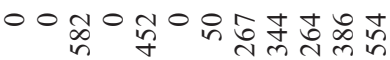

\pm 60 in 6006 in 60 in







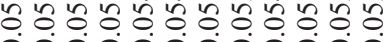

ڤ

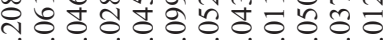

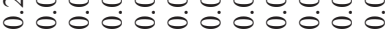

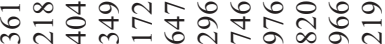
กิ๊ సี

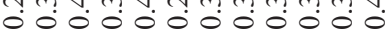

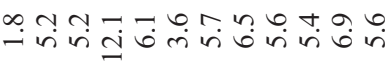


000000000000 mringror $\cos 0 \infty 0$

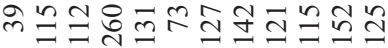



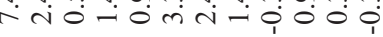
ธ్

苟

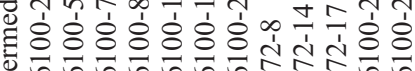
至 
究舟品商





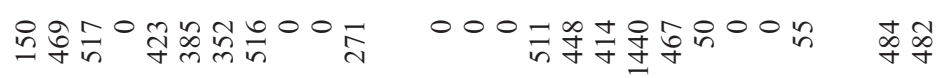

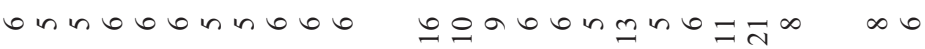

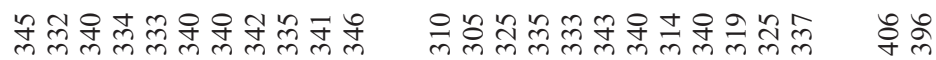

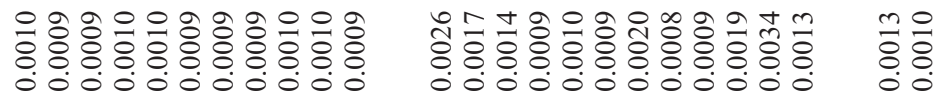

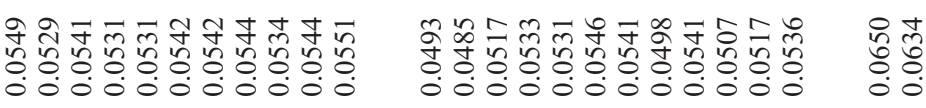

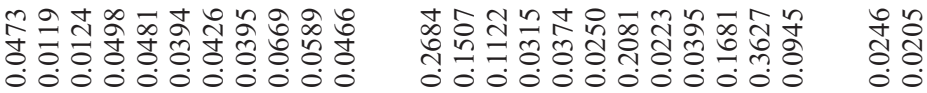

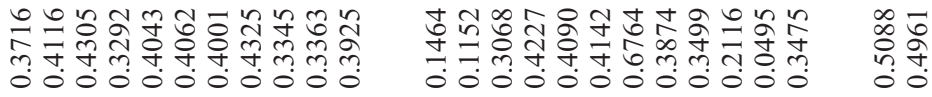

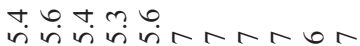



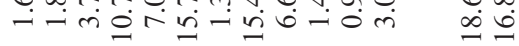



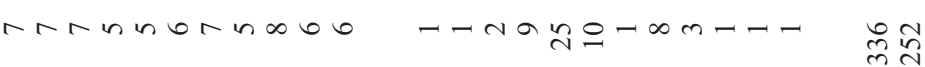

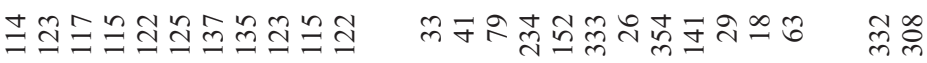

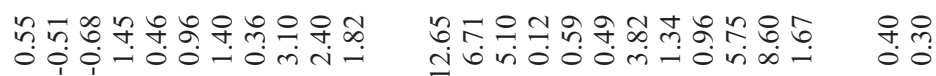

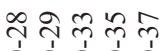

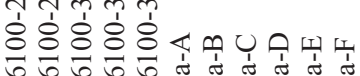





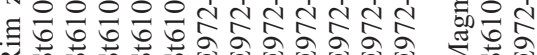


Brazil (Seydoux-Guillaume et al., 2002). We determined an average age of $490 \pm 10(2 \sigma) \mathrm{Ma}$ and $480 \pm 4 \mathrm{Ma}$, using 30 analyses at $30 \mathrm{nA}$ and 25 analyses at $200 \mathrm{nA}$, respectively. These values are close to the age of $474 \pm 1 \mathrm{Ma}$ previously determined by Seydoux-Guillaume et al. (2002) using a SHRIMP.

We also used the EMP to prepare X-ray maps for Fe, Ti, Sn, U and Hf in selected zircons. For the corresponding scanning procedure we used steps of $1 \mu \mathrm{m}$, a counting time of $0.1 \mathrm{~s}$ per step, $15 \mathrm{kV}$ acceleration voltage and a beam current of $20 \mathrm{nA}$.

\section{Results}

Zircon

Areas on the polished zircons which appeared to be homogeneous under CL and large enough for the ion beam spot (see Fig. 4), were selected for SHRIMP analysis. In addition, two irregularlyshaped domains of zircon cores with oscillatory zonation (Fig. 3c), typical of magmatic zircon, were analysed. The positions of the ablation craters were checked after the analyses to be sure that no unwanted material from the different domains had been analysed. The analytical results of 58 SHRIMP measurements, including the ages determined from the ${ }^{238} \mathrm{U} /{ }^{206} \mathrm{~Pb},{ }^{235} \mathrm{U} /{ }^{207} \mathrm{~Pb}$ and ${ }^{232} \mathrm{Th} /{ }^{208} \mathrm{~Pb}$ data with $2 \sigma$-errors, are given in Table 1. In order to correctly interpret the determined data, it was important to correctly assign the ages to the three zircon zones specified above. As the observed CL does not allow us to unequivocally assign a specific zircon area to these zones, due to the occurrence of subzones with variable CL intensities (Figs 3 and 4), we also used the measured concentrations of Th and $\mathrm{U}$ (see Fig. 6) to discriminate between these areas. The results showed 21 measurements in the diamond-free zircon cores (at least in a subzone with lowest $\mathrm{CL}$ ), except the two portions with oscillatory zonation, are characterized by $\mathrm{Th} / \mathrm{U}$ ratios $<0.024$ (U contents between $85-780 \mathrm{ppm}$ ) whereas 23 measurements in the diamond-bearing intermediate zone yielded $\mathrm{Th} / \mathrm{U}$ ratios $>0.036$ (and $\leqslant 0.078$ ) and $U$ contents $<260 \mathrm{ppm}$. Hence, the intermediate and metamorphic core of zircon can be sufficiently discriminated by $\mathrm{Th} / \mathrm{U}$ ratios. Using this discrimination tool we had to reject only 2 SHRIMP analyses (not given in Table 1): in one case the $\mathrm{Th} / \mathrm{U}$ ratio suggested the intermediate zircon zone but according to the $\mathrm{CL}$ image the corresponding measurement was undertaken in the core zone. In the second case displayed the opposite problem. The outermost (rim) zone of zircon with significantly lighter CL compared to the other zones could, however, be easily detected but was rarely large enough to allow a SHRIMP measurement exclusively in this zone. Elemental mapping of some zircon grains (Fig. 7) showed that this zone has a lower Hf concentration compared to the metamorphic core and (most) intermediate zones of zircon. We analysed such areas at the rims of 12 different zircons successfully. The $\mathrm{Th} / \mathrm{U}$ ratios in 11 cases

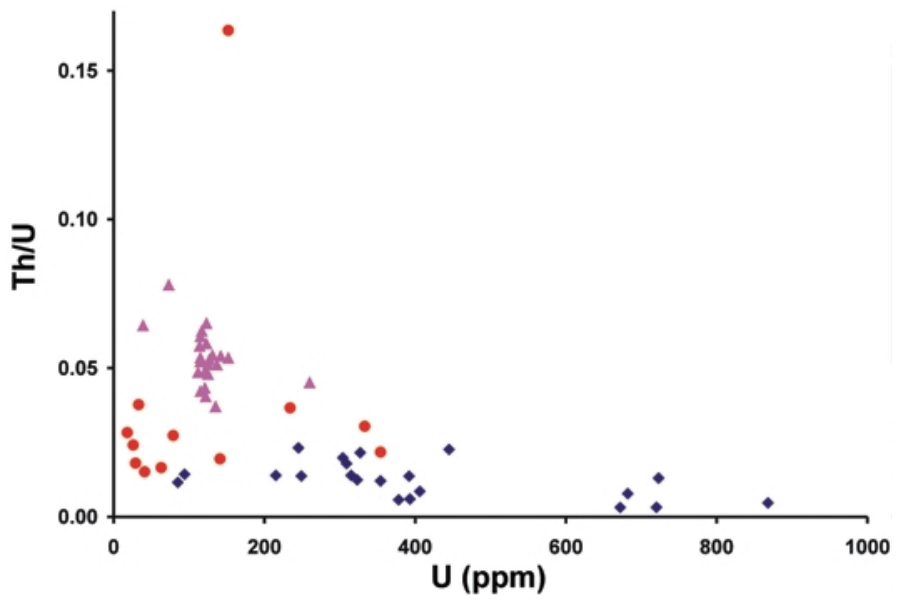

FIG. 6. Uranium content $v s$. Th/U ratio of 21 zircon cores (diamonds), 23 measurements in the microdiamond-bearing intermediate zone of zircon (triangles) and 12 outermost zircon rims with light CL (solid circles). Not shown are the results of two measurements in zircon cores with oscillatory zoning as the $\mathrm{Th} / \mathrm{U}$ ratios were above 0.8 . 

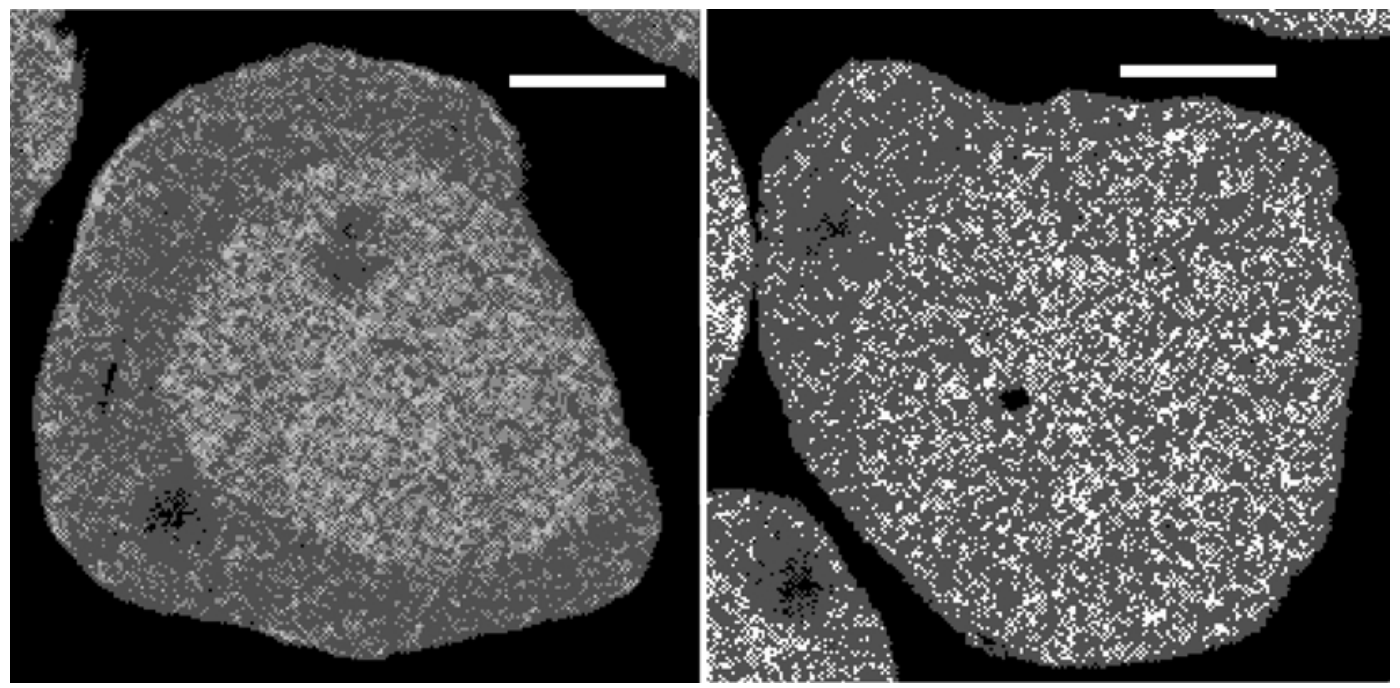

FIG. 7. X-ray maps obtained with the CAMECA SX 100 EMP for Hf in two zircon grains which are shown on the right hand side of Fig. 4. Scale bars represent $50 \mu \mathrm{m}$. Several scanned zircons seem to be homogeneous with respect to Hf contents. In these images, however, the cores show a greater Hf content (brighter area). The rim zone of the zircon on the right hand side is lower in Hf. The same is true for the outer zone of the zircon on the left hand side. This zone was regarded as the intermediate zone $(\mathrm{Th} / \mathrm{U}=0.061$, see Table 1). Ablation pits from the ion probe analyses (see Fig. 4) cause an apparent lowering of the Hf concentration.

$(0.015-0.038)$ are between those of the zircon core and the diamond-bearing intermediate zones including a slight overlap with the $\mathrm{Th} / \mathrm{U}$ ranges of these zones. In one case, however, we observed a relatively high ratio of 0.164 . Even significantly higher are the $\mathrm{Th} / \mathrm{U}$ ratios $(0.82$ and 1.01 not shown in Fig. 5) of the two zircon core domains with magmatic zonation mentioned above. Their $\mathrm{U}$ contents are $\sim 320 \mathrm{ppm}$.

In summary, we obtained the subsequent ages (with $2 \sigma$ error at the $95 \%$ confidence level) on the basis of the contents of ${ }^{206} \mathrm{~Pb},{ }^{207} \mathrm{~Pb},{ }^{235} \mathrm{U}$ and ${ }^{238} \mathrm{U}$ corrected for ${ }^{204} \mathrm{~Pb}$ : (1) zircon core with oscillatory zonation: $\sim 400 \mathrm{Ma}$ ( 2 analyses, see Fig. 8), (2) metamorphic zircon core: $337.0 \pm 2.7 \mathrm{Ma}$ (21 analyses, see Fig. 9), (3) diamond-bearing zone of zircon: $336.8 \pm 2.8 \mathrm{Ma}$ (23 analyses, see Fig. 10) and (4) outer (rim) zone of zircon: $330.2 \pm 5.8 \mathrm{Ma}$ (12 analyses, see Fig. 11). The calculated $2 \sigma$-error ellipses for the means of (2), (3) and (4) lie perfectly on the concordia (Figs 9-11). The error ellipses for the 2 measurements of the magmatic zircon cores also lie on the concordia (Fig. 8), but a true concordant age could not be proven.

\section{Monazite}

The SHRIMP analyses of monazite are given in Table 2. The six corresponding measurements, placed near the centres and rims of monazite crystals, did not indicate any significant age difference. On the basis of ${ }^{206} \mathrm{~Pb},{ }^{207} \mathrm{~Pb},{ }^{235} \mathrm{U}$ and ${ }^{238} \mathrm{U}$ contents corrected for ${ }^{204} \mathrm{~Pb}$, an average

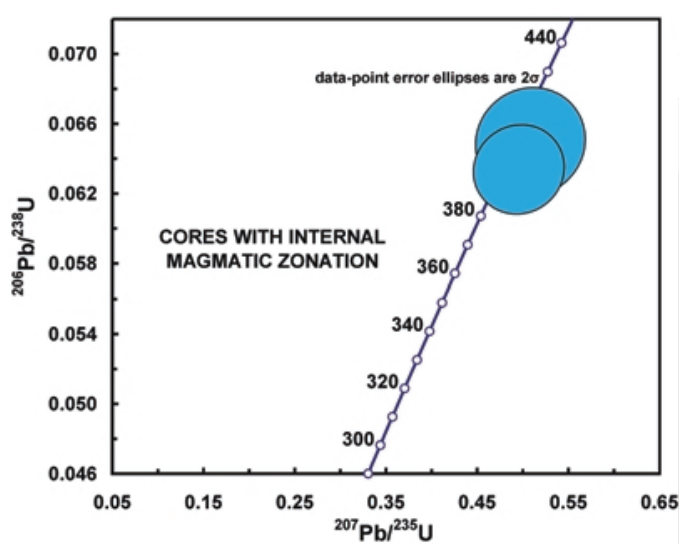

FIG. 8. Concordia diagram of the studied saidenbachites, showing the U-Pb SHRIMP results for 2 zircon cores with oscillatory zoning. 


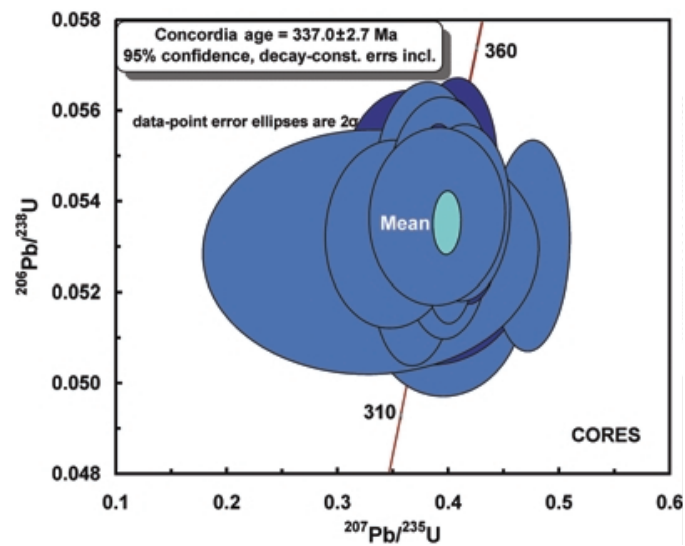

FIG. 9. Concordia diagram of the studied saidenbachites, showing the U-Pb SHRIMP results for 21 zircon cores with $\mathrm{Th} / \mathrm{U}$ ratios $<0.025$.

concordant age of $332.4 \pm 2.1 \mathrm{Ma}$ was obtained (Fig. 12).

Several grains of monazite with partial zonation (see Fig. 5) were analysed in situ by EMP directly in thin sections. The analytical totals of 142 analyses range between 96.3 and 101.4 wt.\% (see Table 3). Normalisation of the elements to eight valences results in phosphorus contents between 0.98 and 1.02 per formula unit, i.e. close to the expected values. Thorium contents of the analysed monazites are generally relatively low, ranging between 0.3 and 7.8 wt. $\% \mathrm{ThO}_{2}$ (mean value: $3.3 \pm 1.7$ wt. $\%$ ). The average value for $\mathrm{UO}_{2}$ is $0.49 \pm 0.24 \mathrm{wt} . \%$. The amount of $\mathrm{Pb}$ formed by radioactive decay is correspondingly very small, ranging from 0.01 to $0.15 \mathrm{wt} \% \mathrm{PbO}$ (mean: $0.08 \pm 0.03$ wt.\%).

For age determinations, the $1 \sigma$ standard deviations of single analyses were calculated by error propagation of the analytical uncertainties of

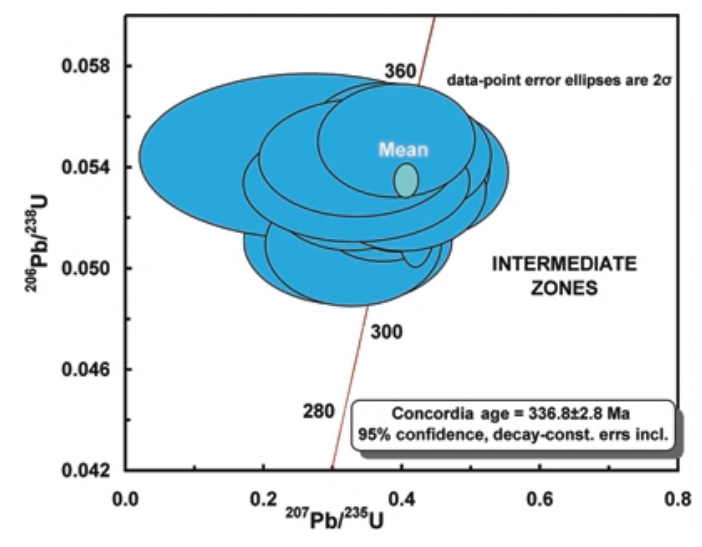

FIG. 10. Concordia diagram of the studied saidenbachites, showing the U-Pb SHRIMP results for 23 zircon intermediate zones ( $\mathrm{Th} / \mathrm{U}$ between $0.037-0.078$ ). Due to the large error, the data for St6100-2 (see Table 1) is not shown.

the single elements based on Poisson statistics. For monazite with intermediate $U$ and $T h$ contents, these $1 \sigma$ values range between 30 and $50 \mathrm{Ma}$ for the $30 \mathrm{nA}$ measurements. This large uncertainty is considerably reduced by multiple measurements. For $n=82$ single measurements performed with $30 \mathrm{nA}$, a $1 \sigma$ standard deviation of the mean $(\mathrm{sdm})$ of $5 \mathrm{Ma}$ results from $\mathrm{sdm}=$ $\left(\Sigma \sigma_{\mathrm{i}}\right)^{0.5} / n$. For 31 analyses $(9$ analyses were ignored due to $\mathrm{ThO}_{2}$ contents $<0.5 \mathrm{wt} . \%$ ) at $200 \mathrm{nA}$, the $1 \sigma$ error of single measurements and the $1 \sigma \mathrm{sdm}$ is only around $10 \mathrm{Ma}$ and $3 \mathrm{Ma}$, respectively. The weighted mean calculated from all 113 analyses is $324.7 \pm 8.0(2 \sigma)$ Ma. This age is consistent with the SHRIMP data from monazite. In addition, there was no statistically significant difference in (mean) ages resulting either from Th-rich core regions of monazite or from outer (rim) regions with smaller Th concentrations.

TABLE 2. Results of U-Pb SHRIMP analyses of monazite from saidenbachite sample E97-2.

\begin{tabular}{|c|c|c|c|c|c|c|c|c|c|}
\hline Spot & $\begin{array}{c}\text { Com } 206 \\
\%\end{array}$ & $\begin{array}{r}- \text { Ratios } \\
{ }^{207} \mathrm{~Pb} /{ }^{235} \mathrm{U}\end{array}$ & $\begin{array}{l}\text { corrected } \\
\quad \pm 1 \sigma\end{array}$ & $\begin{array}{l}\text { for common } \\
{ }^{206} \mathrm{~Pb} /{ }^{238} \mathrm{U}\end{array}$ & $\begin{array}{l}\mathrm{Pb}- \\
\quad \pm 1 \sigma\end{array}$ & ${ }^{206} \mathrm{~Pb} \overline{{ }^{238} \mathrm{U}}$ & $\begin{array}{c}\text { Apparent } \\
\pm 1 \sigma\end{array}$ & $\underset{{ }^{207} \mathrm{~Pb} /{ }^{206} \mathrm{~Pb}}{\text { age in } \mathrm{Ma}}$ & $\pm 1 \sigma$ \\
\hline $\mathrm{mm} 1$ & 1.43 & 0.3814 & 0.0120 & 0.05302 & 0.00048 & 333 & 3 & 293 & 66 \\
\hline $\mathrm{mm} 2$ & 1.38 & 0.3831 & 0.0093 & 0.05246 & 0.00043 & 330 & 3 & 327 & 50 \\
\hline $\mathrm{mm} 3$ & 1.18 & 0.3895 & 0.0081 & 0.05281 & 0.00043 & 332 & 3 & 350 & 41 \\
\hline $\mathrm{mm} 4$ & 1.66 & 0.3828 & 0.0110 & 0.05298 & 0.00046 & 333 & 3 & 303 & 60 \\
\hline $\mathrm{mm} 5$ & 1.04 & 0.3884 & 0.0077 & 0.05324 & 0.00044 & 334 & 3 & 325 & 38 \\
\hline mm6 & 1.02 & 0.3961 & 0.0078 & 0.05294 & 0.00043 & 333 & 3 & 382 & 38 \\
\hline
\end{tabular}




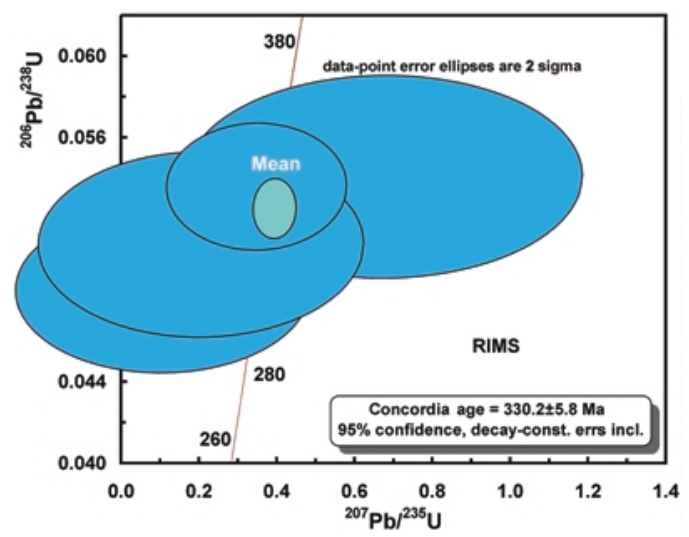

FIG. 11. Concordia diagram of the studied saidenbachites, showing the U-Pb SHRIMP results for 12 zircon rims with $\mathrm{Th} / \mathrm{U}$ ratios $<0.04$ (with one exception at 0.164). Due to the large errors, the data for St6100-3 and E972-18 (see Table 1) are not shown.

\section{Discussion and conclusions}

The zonation of the investigated zircons observed in $\mathrm{CL}$ images and $\mathrm{Th} / \mathrm{U}$ ratios determined by SHRIMP for particular zircon zones, are interpreted here to correspond to different evolutionary stages responsible for the formation of the studied zircons. The $\mathrm{Th} / \mathrm{U}$ ratios of the metamorphic cores of zircon (Fig. 6) as well as the surrounding zones are smaller than 0.1 (only one value gave 0.16 ) and as a result significantly below a value of 0.3 generally accepted as lower limit for magmatic zircons (see Schaltegger et al., 1999; Rubatto et al., 2001). In contrast to the

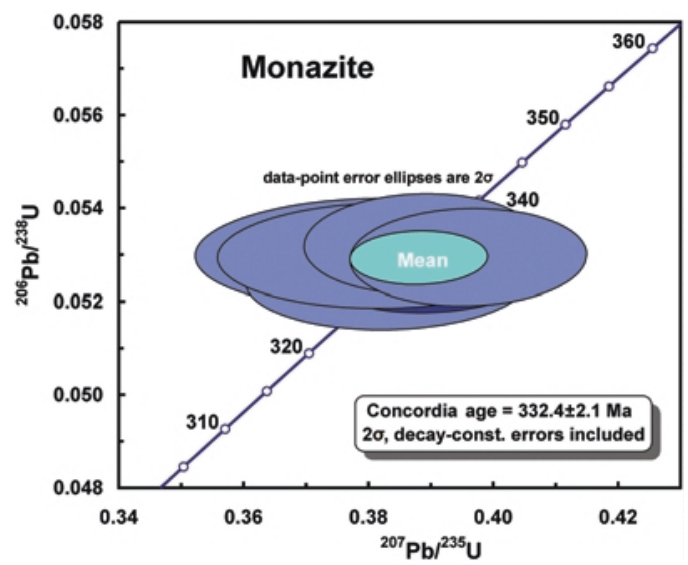

FIG. 12. Concordia diagram showing the U-Pb SHRIMP results for 6 monazites from saidenbachite sample E97-2. majority of the studied zircons, two SHRIMP analyses of zircon cores with oscillatory zoning yielded $\mathrm{Th} / \mathrm{U}$ ratios close to unity (Table 1 ) and ages $\geqslant 400 \mathrm{Ma}$. A possible explanation for these data is that these zircon cores, being relics from igneous rocks, were deposited in the sedimentary protoliths of the saidenbachites. Such sediments must have formed no earlier than late LowerDevonian. The provenance of these sediments could be the Mid-German crystalline rise, as $\mathrm{U}-\mathrm{Pb}$ ages in the range 400-420 Ma have been reported for igneous rocks of the Spessart crystalline complex (Dombrowski et al., 1995) and the Ruhla crystalline complex (Brätz, 2000).

More importantly for our discussion, however, is the fact that these zircons, which gave concordant ages (Fig. 8), do not seem to have suffered significant $\mathrm{Pb}$ loss despite suffering temperatures $>1000^{\circ} \mathrm{C}$ during UHP metamorphism (Massonne, 2003). The assumed lack of resetting of the ages close to $400 \mathrm{Ma}$ is supported by Connelly (2000) who generalized that preserved zircon cores with oscillatory zoning are (nearly) concordant.

\section{Hints at burial and exhumation velocities}

The low CL subzones of the metamorphic core of zircon in the studied saidenbachites gave a mean age of $337.0 \pm 2.7 \mathrm{Ma}$ (Fig. 9). This age is close to previous dating results of the Erzgebirge gneisses, pointing to HP metamorphism at $\sim 340 \mathrm{Ma}$ (Kröner and Willner, 1998; Tichomirowa et al., 2005). The $\mathrm{Th} / \mathrm{U}$ ratios and $\mathrm{U}$ contents of the analysed metamorphic cores are very small and relatively large, respectively. Tichomirowa et al. (2005) also observed zircons with these characteristics from various gneisses of the central Erzgebirge, and argued that these compositions are due to U-Th fractionation in the presence of a fluid phase. Carbon dioxide rich fluids have been shown to be particularly effective at fractionating $\mathrm{U}$ relative to Th (Keppler and Wyllie, 1990), although only native carbon is known to be present in the saidenbachites. Such fluids might have formed during HP metamorphism as the studied metamorphic zircon cores (here again the low CL subzones) contain inclusions of the HP mineral jadeite, which formed under $P-T$ conditions of $\sim 1.8 \mathrm{GPa}(\sim 60 \mathrm{~km}$ depth$)$ and $650^{\circ} \mathrm{C}$ (Massonne and Nasdala, 2003). Conversely, the metamorphic zircon cores could have formed during burial to depths $>60 \mathrm{~km}$ or even close to maximum depths (150 to possibly $240 \mathrm{~km}$ ) when 
TABLE 3. Representative $30 \mathrm{nA}$ EMP analyses of monazite (normalization to 8 valencies) with different Th content from sample E97-2. Contents of S, Eu, and Dy were below detection limit. The age was calculated according to Scherrer et al. (2000).

\begin{tabular}{|c|c|c|c|c|c|}
\hline $\begin{array}{l}\text { Analysis } \\
\text { Grain }\end{array}$ & $\begin{array}{c}5 \mathrm{a} \\
1\end{array}$ & $\begin{array}{c}32 \mathrm{a} \\
4\end{array}$ & $\begin{array}{c}35 \mathrm{a} \\
4\end{array}$ & $\begin{array}{c}66 a \\
6\end{array}$ & $\begin{array}{c}8 b \\
6\end{array}$ \\
\hline $\mathrm{SiO}_{2}$ (all in wt.\%) & 0.049 & 0.152 & 0.047 & 0.096 & 0.272 \\
\hline $\mathrm{P}_{2} \mathrm{O}_{5}$ & 30.746 & 29.844 & 30.449 & 30.256 & 30.008 \\
\hline $\mathrm{CaO}$ & 0.627 & 0.704 & 0.424 & 1.341 & 0.938 \\
\hline $\mathrm{Y}_{2} \mathrm{O}_{3}$ & 0.260 & 0.146 & 0.283 & 0.248 & 0.224 \\
\hline $\mathrm{La}_{2} \mathrm{O}_{3}$ & 16.806 & 15.407 & 15.736 & 13.134 & 13.536 \\
\hline $\mathrm{Ce}_{2} \mathrm{O}_{3}$ & 29.858 & 29.812 & 30.957 & 26.402 & 27.975 \\
\hline $\mathrm{Pr}_{2} \mathrm{O}_{3}$ & 3.240 & 3.366 & 3.561 & 3.125 & 3.215 \\
\hline $\mathrm{Nd}_{2} \mathrm{O}_{3}$ & 11.125 & 12.166 & 12.526 & 11.738 & 12.459 \\
\hline $\mathrm{Sm}_{2} \mathrm{O}_{3}$ & 1.629 & 1.712 & 1.956 & 1.966 & 2.075 \\
\hline $\mathrm{Gd}_{2} \mathrm{O}_{3}$ & 0.702 & 0.552 & 0.839 & 0.581 & 0.739 \\
\hline $\mathrm{PbO}$ & 0.0625 & 0.0776 & 0.0269 & 0.1455 & 0.1045 \\
\hline $\mathrm{ThO}_{2}$ & 2.616 & 3.740 & 0.932 & 7.491 & 5.459 \\
\hline $\mathrm{UO}_{2}$ & 0.482 & 0.407 & 0.385 & 0.624 & 0.561 \\
\hline Total & 98.216 & 98.105 & 98.126 & 97.185 & 97.593 \\
\hline $\mathrm{Si}$ & 0.0019 & 0.0060 & 0.0019 & 0.0038 & 0.0108 \\
\hline $\mathrm{P}$ & 1.0198 & 1.0040 & 1.0147 & 1.0177 & 1.0088 \\
\hline $\mathrm{Ca}$ & 0.0263 & 0.0300 & 0.0179 & 0.0571 & 0.0399 \\
\hline $\mathrm{Y}$ & 0.0054 & 0.0031 & 0.0059 & 0.0052 & 0.0047 \\
\hline $\mathrm{La}$ & 0.2429 & 0.2258 & 0.2285 & 0.1925 & 0.1982 \\
\hline $\mathrm{Ce}$ & 0.4283 & 0.4337 & 0.4461 & 0.3841 & 0.4067 \\
\hline $\operatorname{Pr}$ & 0.0462 & 0.0487 & 0.0511 & 0.0452 & 0.0465 \\
\hline $\mathrm{Nd}$ & 0.1557 & 0.1726 & 0.1761 & 0.1666 & 0.1767 \\
\hline $\mathrm{Sm}$ & 0.0220 & 0.0234 & 0.0265 & 0.0269 & 0.0284 \\
\hline $\mathrm{Gd}$ & 0.0091 & 0.0073 & 0.0110 & 0.0077 & 0.0097 \\
\hline $\mathrm{Pb}$ & 0.00066 & 0.00083 & 0.00029 & 0.00156 & 0.00112 \\
\hline Th & 0.0233 & 0.0338 & 0.0083 & 0.0677 & 0.0493 \\
\hline U & 0.0043 & 0.0038 & 0.0034 & 0.0058 & 0.0052 \\
\hline Sum cations & 1.9859 & 1.9931 & 1.9917 & 1.9819 & 1.9861 \\
\hline Age (Ma) & 353 & 362 & 293 & 361 & 339 \\
\hline
\end{tabular}

phengite dehydration melting occurred. According to HP experiments using clastic sediment compositions (see Patiño Douce and McCarthy, 1998), phengite dehydration melting ought to have taken place at $\sim 950^{\circ} \mathrm{C}(5 \mathrm{GPa})$ or greater $(>5 \mathrm{GPa})$. However, it seems unlikely that the zircon cores have formed from the generated melt (or supercritical $\mathrm{COH}$ silicate fluid - see Stöckhert et al., 2001) because the very low $\mathrm{Ti}$ contents of the enclosed garnet in these cores clearly points to temperatures $<1000^{\circ} \mathrm{C}$ (Massonne and Nasdala, 2003). Under these conditions, the metamorphic zircon cores could have formed during burial to great depths within a time span as short as $10^{6}$ years, as the $2 \sigma$-error of age determination amounts to $\pm 2.7 \mathrm{Ma}$. This would explain why there is already a significant difference $(3.5 \pm 2.9 \quad(2 \sigma) \mathrm{Ma}$ considering Gaussian distribution and corresponding error propagation) between the concordant age of $340.5 \pm 1.1 \mathrm{Ma}$ determined for the HP metamorphism of a metapelite, also taken from the Saidenbach reservoir (E 42x: Kröner and Willner, 1998) and our zircon cores (a contemporaneous event has a probability of only $0.8 \%$ ). If we relate the time span of $6.4 \mathrm{Ma}$ (mean difference of $3.5 \mathrm{Ma}+2 \sigma(2.9 \mathrm{Ma}))$ to burial from $60 \mathrm{~km}$ (related to HP metamorphism of $\mathrm{E} 42 \mathrm{x}$ ) to $150 \mathrm{~km}$ (minimum depth related to maximum burial of the saidenbachites), the minimum burial rate amounts to $1.4 \mathrm{~cm} /$ year. This, or even a significantly greater velocity $(3.4 \mathrm{~cm} /$ year results 
from the average values of $3.5 \mathrm{Ma}$ and a $120 \mathrm{~km}$ difference in depth), for downwards directed mass transport, can be reached in subduction zones and probably also by delamination of the lithosphere involving crustal rocks, such as metasediments (with the composition of saidenbachites), from the base of the orogenically thickened continental crust (Massonne, 2005).

At, or close to, the maximum burial depth, temperatures of the saidenbachites reached $1100^{\circ} \mathrm{C}$ to $1200^{\circ} \mathrm{C}$ (Massonne, 2003) depending on the maximum burial depth. As a result temperatures for phengite dehydration melting, mentioned earlier, were clearly reached and exceeded, resulting in extensively melted rocks. Zircon was considerably corroded (see low CL zircon cores in Fig. 4 and in the centre of Fig. $3 b$ ) by this melting process. As the density of the generated melt (mash) is lower than that of the corresponding (kyanite-garnet-phengite-jadeitecoesite-bearing) rock, being close to that of an ordinary garnet peridotite (Massonne et al., 2007), the silicate melt (or supercritical silicate fluid) ascended. During contemporaneous cooling (see, for instance, $P-T$ path by Massonne and O'Brien, 2003 ) this melt crystallized, according to petrological observations, leading to the overgrowth of zircon cores by the intermediate zone. This zircon growth continued at UHP conditions, since abundant microdiamonds, which probably also crystallized from the silicate melt (Massonne, 2003), were trapped in growing zircon grains before transformation to graphite at HP conditions, a fate probably met by the majority of microdiamonds. During crystallization from the melt, zircon did not develop oscillatory zoning nor $\mathrm{Th} / \mathrm{U}$ ratios $>0.3$. Hemce, such characteristics only seem to apply to specific magmatic zircons, possibly only to those formed in magma chambers of the upper crust. The age of the intermediate zircon zone was determined to be virtually the same as that of the core zone. Assuming again Gaussian distributions for the age-determinations with corresponding error propagation, the difference in time is $0.2 \pm 3.9(2 \sigma)$ Ma. Considering a probability of $95 \%$, the time difference between the formation of the core and intermediate zones is at least $<3.5$ million years (note that the intermediate zone cannot be older than the core). As a result, the minimum exhumation rate is already in the $\mathrm{cm} /$ year range. However, if we consider the time difference of $3.6 \pm 3.0 \mathrm{Ma}$ between the formation of HP zircon in E 42x and the zircon (without rim zone) studied here and a probability of $95 \%$ again, the time difference is at a minimum $<6.1$ million years. Within this time interval, the saidenbachites have experienced a downwards and (subsequently) upwards directed mass flow covering a vertical distance of at least $120 \mathrm{~km}$ ( $P-T$ path shown by Stöckhert et al., 2001). Thus, an average minimum velocity of 2 $\mathrm{cm} /$ year results for both burial from the base (60 $\mathrm{km}$ depth corresponding to a pressure of $1.8 \mathrm{GPa})$ of a thickened continental crust and exhumation (halfway?) back towards the base (50 km depth) of a still thickened crust. It is generally thought that the ascent of a silicate melt (mash) can be a fairly quick process, hence a likely model involves burial velocities between 2 and $5 \mathrm{~cm} /$ year and exhumation with a velocity $>10 \mathrm{~cm} /$ year (Fig. 14) before complete crystallization of the melt at a deep crustal level corresponding to a pressure of $1.5 \mathrm{GPa}$ (Massonne, 2003). This rapid exhumation could conflict with the deduced cooling (from $>1050^{\circ} \mathrm{C}$ at $P>5.0 \mathrm{GPa}$ to $750^{\circ} \mathrm{C}$ at $1.5 \mathrm{GPa}$ ) of the melt since solely adiabatic cooling during pressure release is not sufficient. At least for larger UHPHP rock complexes, fast exhumation in the $\mathrm{cm}$ per-year range implies a nearly isothermal process (e.g. Grasemann et al., 1998). However, an ascending, relatively small melt bleb (with a size similar to that of the saidenbachite lenses) with internal convection could undergo extensive thermal equilibration with the surrounding material despite high exhumation rates.

\section{Comparison with exhumation velocities of other UHP areas}

There are no reasonable estimates for the burial velocities of UHP-HP rock complexes with the exception of the typical rates of mass transport in subduction zones. We therefore focus the following discussion on exhumation rates. A value of $2.2 \mathrm{~cm} /$ year was given by Gebauer et al. (1997) for the exhumation of UHP rocks from the Dora Maira Massif, Western Alps. Rubatto and Hermann (2001) estimated an even greater rate of $3.4 \mathrm{~cm} /$ year for the beginning of the exhumation of these rocks from maximum depth. A similar value $(2.3-4.5 \mathrm{~cm} /$ year $)$ was reported for the beginning of exhumation of UHP rocks of the western Himalaya (O'Brien and Sachan, 2000). Hence, velocities in the range of a few $\mathrm{cm} /$ year seem to be typical for early exhumation of UHP rock complexes. However, such velocities refer to the ascent of solid material $\left(T \leqslant 750^{\circ} \mathrm{C}\right)$. 
The idea of a UHP melt (mash), ascending with relatively high velocity, was also related by Massonne (2003) to diamondiferous rocks from the Kokchetav Massif (Lake Kumdy-Kol) for which Hermann et al. (2001) deduced a minimum exhumation rate of only $1.8 \mathrm{~cm} /$ year. However, we believe that the true exhumation rate could significantly exceed the minimum estimate by Hermann et al. (2001) as the errors of the corresponding age determinations were relatively high. Reducing the probability, for instance, to $80 \%$, the data from Hermann et al. (2001) points to a time span $<3$ million years and, as a result to a minimum exhumation rate of $5 \mathrm{~cm} /$ year, during pressure release from $6.5 \mathrm{GPa}$ to $1.2 \mathrm{GPa}$ (see Massonne, 2003). Hence, the above assumption $(>10 \mathrm{~cm} /$ year, Fig. 14) for the exhumation rate of the saidenbachites from the Saxonian Erzgebirge could also hold true for the UHP rocks from Lake Kumdy-Kol.

\section{Late metamorphic event}

The formation of thin zircon rims (Figs 3 and 11), again with very low $\mathrm{Th} / \mathrm{U}$ ratios, occurred possibly some million years after the growth of the core and intermediate zones. The reason for the overgrowth (more likely than recrystallization as the change in $\mathrm{Hf}$ content is fairly abrupt at the border of the rim zone of zircon; see Fig. 7) of the intermediate domain of zircon is not known. Many zircons in the separated population even do not exhibit such an overgrowth (see Fig. 3). We speculate that the formation of this outer zircon zone is due to a late-stage influx of hydrous fluids or to those generated internally by the (partial) alteration of phengitic muscovite to muscovite (+ K-feldspar and quartz according to the reaction: 3 celadonite component in white mica, $\mathrm{KAl}\left(\mathrm{Mg}, \mathrm{Fe}^{2+}\right) \mathrm{Si}_{4} \mathrm{O}_{10}(\mathrm{OH})_{2}=$ phlogopite-annite component in dark mica, $\mathrm{K}\left(\mathrm{Mg}, \mathrm{Fe}^{2+}\right)_{3}$ $\mathrm{AlSi}_{3} \mathrm{O}_{10}(\mathrm{OH})_{2}+2$ K-feldspar, $\mathrm{KAlSi}_{3} \mathrm{O}_{8}+$ 3 quartz, $\mathrm{SiO}_{2}+2 \mathrm{H}_{2} \mathrm{O}$ ) and biotite, often discernable along the rims of potassic white mica, during further pressure release. Such a process, which probably also resulted in the replacement of kyanite by large flakes of muscovite, took place while temperatures were still high (probably $>600{ }^{\circ} \mathrm{C}$ ). We also infer that monazite mainly formed by the same process, as only one example of a microdiamond inclusion in the core of a monazite grain was found (Fig. 5). Our SHRIMP measurements are compatible with this observation as zircon rims and monazites gave ages of $330.2 \pm 5.8 \mathrm{Ma}$ and $332.4 \pm 2.1 \mathrm{Ma}$, respectively. Electron microprobe dating of monazite yielded a younger mean age


zite directly enclosing the microdiamond in Fig. 5 contains $\sim 4$ wt. $\% \mathrm{ThO}_{2}$; compare with analyses given in Table 3) commenced growth at an early exhumation stage. However, the majority of monazite with relatively low $\mathrm{ThO}_{2}$ contents ( $<3$ wt.\%, often observed for monazite rims) formed during a late, possibly metamorphic, event $(P \leqslant 1.5 \mathrm{GPa})$ compatible with petrological observations. Possibly during a very late metamorphic stage monazites with greater Th contents crystallized (see Fig. 5). However, the chemical profiles of monazites with two zones shown in Fig. 5 could also be interpreted in another way: (1) early monazites were low in Th (core of grain 2 in Fig. 5b), (2) Th-rich monazites represent an intermediate zone enclosing microdiamond (core of grain 1 in Fig. 5a), (3) late monazite (rim of grain 1 and other monazites as well) are again relatively poor in $\mathrm{Th}$. As the $\mathrm{U}$ contents of our monazites are not as variable as the Th contents (see Table 3), the $\mathrm{Th} / \mathrm{U}$ ratios would be greatest for the intermediate zone if the latter interpretation is correct. This is identical behaviour to that observed for zircons (intermediate zone with the greatest $\mathrm{Th} / \mathrm{U}$ ratios around 0.055 ). Unfortunately, due to the relatively large error of the EMP dating method, we were not able to distinguish between monazite cores and extended rims, which may be some million years younger, as was possible for the zircons using a SHRIMP.

According to the above discussion, data from zircon rims and monazite (Figs 11-13) support a late event which occurred between 332 to $330 \mathrm{Ma}$. Similar ages were reported as cooling ages on the basis of ${ }^{40} \mathrm{Ar} /{ }^{39} \mathrm{Ar}$ dating of white micas from the Saxonian Erzgebirge (Werner and Lippolt, 2000). In addition, Werner and Reich (1997) determined comparable cooling ages from schists surrounding the nearby Saxonian Granulitgebirge. However, intrusions of granitoids occurred here in the same time interval as shown in Nasdala et al. (1996). The $\mathrm{Rb} / \mathrm{Sr}$ (cooling) age of $323 \mathrm{Ma}$ for biotite from a granulite of the Saxonian Granulitgebirge obtained by Romer and Rötzler (2001), is a clear indication that the crystalline massifs at least of the northern Bohemian Massif had already cooled down significantly in late Lower Carboniferous times. It is possible that these massifs (but not the present erosion level) were at 


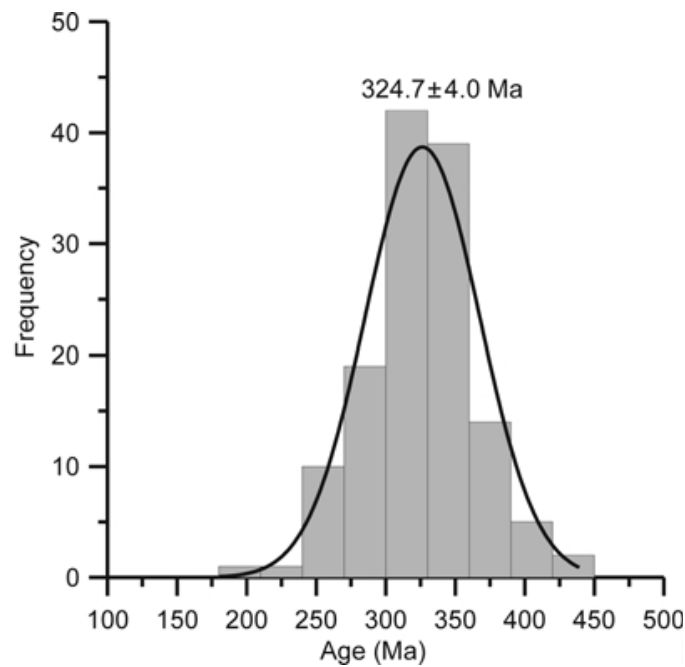

FIG. 13. Histogram related to the EMP dating of monazites from thin sections of sample E97-2.

or close to the surface. From the above data we have estimated that the average exhumation rate was $\sim 0.5 \mathrm{~cm} / \mathrm{y}$ (Fig. 14) since the saidenbachites reached the base of a still thickened continental crust after the initial fast exhumation phase.

\section{Acknowledgements}

This work was financially supported by Deutsche Forschungsgemeinschaft (Ma 1160/19). The SHRIMP specimens were prepared by Dieter Dettmar, Ruhr-Universität Bochum. Leo Hartmann, of UFRGS at Porto Alegre, kindly provided the fragment of the gem-quality monazite. This paper benefited from reviews by M. Jercinovic, A. Liati and B. Monteleone.

\section{References}

Brätz, H. (2000) Radiometrische altersdatierung und geochemische untersuchungen von orthogneisen, graniten und granitporphyren aus dem ruhlaer kristallin, Mitteldeutsche Kristallinzone. $\mathrm{PhD}$ thesis, Universität Würzburg, 151 pp.

Breitkreuz, C. and Kennedy, A.K. (1999) Magmatic flare-up at the Carboniferous/Permian boundary in the NE German Basin revealed by SHRIMP zircon ages. Tectonophysics, 302, 307-326.

Chopin, C. (2003) Ultrahigh pressure metamorphism: tracing continental crust into the mantle. Earth and Planetary Science Letters, 212, 1-14.

Claoue-Long, J.C., Sobolev, N.V., Shatsky, V.S. and Sobolev, A.V. (1991) Zircon response to diamondpressure metamorphism in the Kokchetav massif. Geology, 19, 710-713.

Compston, W., Williams, I.S. and Meyer, C. (1984) U$\mathrm{Pb}$ geochronology of zircons from lunar breccia

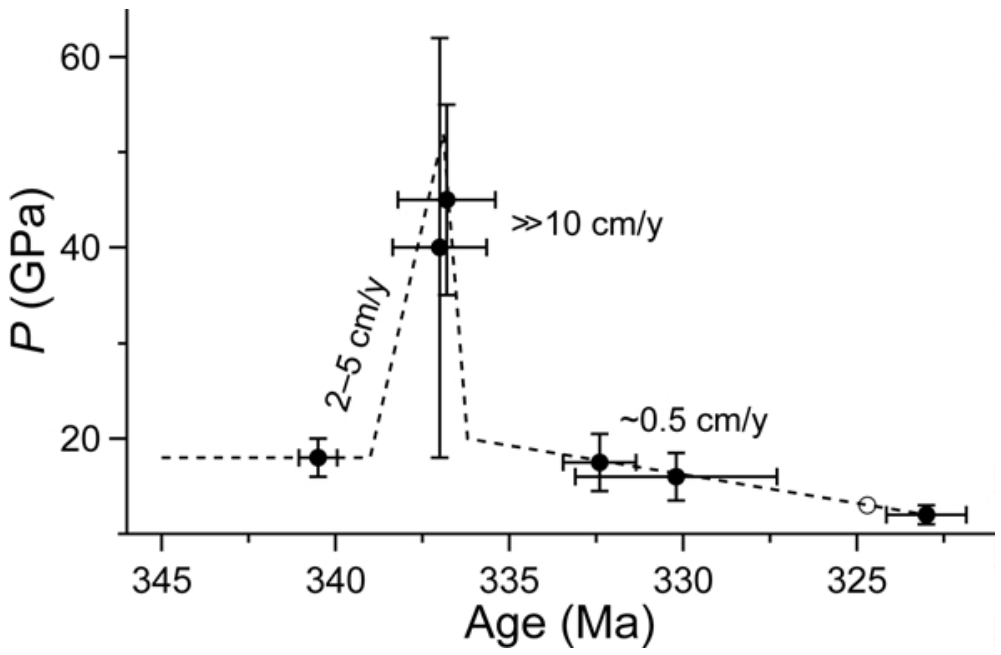

FIG. 14. Pressure-time diagram displaying a likely burial and exhumation course for saidenbachites from the Saxonian Erzgebirge during an episode of the Variscan orogeny. Error bars for time are related to $1 \sigma$. The open circle represents the mean age acquired via EMP dating of monazite from this study (see Fig. 13). The age at 340.5 $\mathrm{Ma}$ is for sample E 42x, dated by Kröner and Willner (1998). The age at $323 \mathrm{Ma}$ is a Rb-Sr biotite (cooling) age determined for a granulite from the Granulitgebirge by Romer and Rötzler (2001). 


\section{H. J. MASSONNE ET AL.}

73217 using a sensitive high mass-resolution ion microprobe. Proceedings of the $14^{\text {th }}$ LPSC, Part 2, Journal of Geophysical Research, 89B, 525-534.

Connelly, J.N. (2000) Degree of preservation of igneous zonation in zircon as a signpost for concordancy in $\mathrm{U} / \mathrm{Pb}$ geochronology. Chemical Geology, 172, 25-39.

De Laeter, J.R. and Kennedy, A.K. (1998) A double focusing mass spectrometer for geochronology. International Journal of Mass Spectrometry and Ion Processes, 178, 43-50.

Dombrowski, A., Henjes-Kunst, F., Höhndorf, A., Kröner, A., Okrusch, M. and Richter, P. (1995) Orthogneisses in the Spessart Crystalline Complex, northwest Bavaria: witnesses of Silurian granitoid magmatism at an active continental margin. Geologische Rundschau, 84, 399-411.

Düffels, K. and Massonne, H.-J. (2001) Geochemical signatures of diamondiferous gneisses and their adjacent rocks from the Erzgebirge, Germany. Terra Nostra, 5, 24-26.

Gebauer, D., Schertl, H.-P., Brix, M. and Schreyer, W. (1997) 35 Ma old ultrahigh-pressure metamorphism and evidence for very rapid exhumation in the Dora Maira Massif, Western Alps. Lithos, 41, 5-24.

Grasemann, B., Ratschbacher, L. and Hacker, B.R. (1998) Exhumation of ultrahigh-pressure rocks: thermal boundary conditions and cooling history. Pp. 117-139 in: When Continents Collide: Geodynamics and Geochemistry of Ultrahigh-pressure Rocks (B.R. Hacker and J.G. Liou, editors). Kluwer Academic Publishers, Norwell Dordrecht.

Hermann, J., Rubatto, D., Korsakov, A. and Shatsky, V.S. (2001) Multiple zircon growth during fast exhumation of diamondiferous, deeply subducted continental crust (Kokchetav Massif, Kazakhstan). Contributions to Mineralogy and Petrology, 141, $66-82$.

Jercinovic, M.J. and Williams, M.L. (2005) Analytical perils (and progress) in electron microprobe trace element analysis applied to geochronology: background acquisition interferences, and beam irradiation effects. American Mineralogist, 90, 526-546.

Katayama, I., Zayachkovsky, A.A. and Maruyama, S. (2000) Prograde pressure-temperature records from inclusions in zircons from ultrahigh-pressure - highpressure rocks of the Kokchetav Massif, northern Kazakhstan. The Island Arc, 9, 417-427.

Kennedy, A.K. (2000) The search for new zircon standards for SIMS. Pp. 109-111 in: Beyond 2000: New Frontiers in Isotope Geoscience, Lorne, Abstracts and Proceedings (J.D. Woodhead, J.M. Hergt and W.P. Noble, editors).

Keppler, H. and Wyllie, P.J. (1990) Role of fluids in transport and fractionation of uranium and thorium in magmatic processes. Nature, 348, 531-533.
Kröner, A. and Willner, A.P. (1998) Time of formation and peak of Variscan HP-HT metamorphism of quartz-feldspar rocks in the central Erzgebirge, Saxony, Germany. Contributions to Mineralogy and Petrology, 132, 1-20.

Ludwig, K.R. (1999) Isoplot/Ex, version 2.06: A geochronological tool-kit for Microsoft Excel. Special Publication 1a, Berkeley Geochronology Center, 1-49.

Massonne, H.-J. (2001) First find of coesite in the ultrahigh-pressure metamorphic region of the Central Erzgebirge, Germany. European Journal of Mineralogy, 13, 565-570.

Massonne, H.-J. (2003) A comparison of the evolution of diamondiferous quartz-rich rocks from the Saxonian Erzgebirge and the Kokchetav Massif: are so-called diamondiferous gneisses magmatic rocks? Earth and Planetary Science Letters, 216, $345-362$.

Massonne, H.-J. (2005) Involvement of crustal material in delamination of the lithosphere after continentcontinent collision. International Geology Review, 47, 792-804.

Massonne, H.-J. and Nasdala, L. (2003) Characterization of an early metamorphic stage through inclusions in zircon of a diamondiferous quartzofeldspathic rock from the Erzgebirge, Germany. American Mineralogist, 88, 883-889.

Massonne, H.-J. and O'Brien, P.J. (2003) The Bohemian Massif and the NW Himalaya. Pp. 145-187 in: Ultrahigh Pressure Metamorphism (D.A. Carswell and R. Compagnoni, editors), EMU Notes in Mineralogy, 5.

Massonne, H.-J. and Neuser, R. (2005) Ilmenite exsolution in olivine from the serpentinite body at Zöblitz, Saxonian Erzgebirge. Mineralogical Magazine, 69, 119-124.

Massonne, H.-J., Bernhardt, H.J., Dettmar, D., Kessler, E., Medenbach, O. and Westphal, T. (1998) Simple identification and quantification of microdiamonds in rock thin-sections. European Journal of Mineralogy, 10, 497-504.

Massonne, H.-J., Nasdala, L. and Kennedy, A. (2001) U$\mathrm{Th}-\mathrm{Pb}$ dating of zircons and monazites from diamondiferous gneisses of the Saxonian Erzgebirge - implications for their UHP/HP evolution. 6th International Eclogite Conference, Niihama, Japan, Abstract Volume, 88.

Massonne, H.-J., Willner, A.P. and Gerya, T.V. (2007) Densities of metapelitic rocks at high to ultrahigh pressure conditions: what are the geodynamic consequences? Earth and Planetary Science Letters, 256, 12-27.

Nasdala, L. and Massonne, H.-J. (2000) Microdiamonds from the Saxonian Erzgebirge, Germany: in situ micro-Raman characterisation. European Journal of 
Mineralogy, 12, 495-498.

Nasdala, L., Gruner, T., Nemchin, A.A., Pidgeon, R.T. and Tichomirowa, M. (1996) New SHRIMP ion microprobe measurements on zircons from Saxonian magmatic and metamorphic rocks. Freiberger Isotopenkolloquium, Proceedings, 205-214.

O'Brien, P.J. and Sachan, H.K. (2000) Diffusion modelling in garnet from Tso Morari eclogite and implications for exhumation models. Earth Science Frontiers, 7, 25-27.

Ota, T., Terabayashi, M., Parkinson, C.D. and Masago, H. (2000) Thermobaric structure of the Kokchetav ultrahigh-pressure - high-pressure massif deduced from a north-south transect in the Kulet and SaldatKol regions, northern Kazakhstan. The Island Arc, 9, 328-357.

Patiño Douce, A.E. and McCarthy, T.C. (1998) Melting of crustal rocks during continental collision and subduction. Pp. 27-55 in: When Continents Collide: Geodynamics and Geochemistry of Ultrahigh-pressure Rocks (B.R. Hacker and J.G. Liou, editors). Kluwer Academic Publishers, Norwell Dordrecht.

Pyle, J.M., Spear, F.S., Wark, D.A., Daniel, C.G. and Storm, L.C. (2005) Contributions to precision and accuracy of chemical ages of monazite. American Mineralogist, 90, 547-577.

Reed, S.J.B. and Buckley, A. (1998) Rare-earth element determination in minerals by electron-probe microanalysis: application of spectrum synthesis. Mineralogical Magazine, 62, 1-8.

Romer, R.L. and Rötzler, J. (2001) P-T-t evolution of ultrahigh-temperature granulites from the Saxon Granulite Massif, Germany. Part II: Geochronology. Journal of Petrology, 42, 2015-2032.

Rubatto, D. and Hermann, J. (2001) Exhumation as fast as subduction? Geology, 29, 3-6.

Rubatto, D., Williams, I.S. and Buick, I.S. (2001) Zircon and monazite response to prograde metamorphism in the Reynolds Range, central Australia. Contributions to Mineralogy and Petrology, 140, 458-468.

Schaltegger, U., Fanning, C.M., Günther, D., Maurin, J.C., Schulmann, K. and Gebauer, D. (1999) Growth, annealing and recrystallization of zircon and preservation of monazite in high-grade metamorphism: conventional and in-situ U-Pb isotope, cathodoluminescence and microchemical evidence. Contributions to Mineralogy and Petrology, 134, 186-201.

Scherrer, N.C., Engi, M., Gnos, E., Jakob, V. and Liechti, A. (2000) Monazite analysis; from sample preparation to microprobe age dating and REE quantification. Schweizerische Mineralogische und Petrographische Mitteilungen, 80, 93-105.

Seydoux-Guillaume, A.-M., Paquette, J.-L., Wiedenbeck, M., Montel, J.-M. and Heinrich W.
(2002) Experimental resetting of the U-Th- $\mathrm{Pb}$ systems in monazite. Chemical Geology, 191, 165-181.

Shatsky, V.S., Sobolev, N.V. and Vavilow, M.A. (1995) Diamond-bearing metamorphic rocks of the Kokchetav Massif (Northern Kazakhstan). Pp. 427-455 in: Ultrahigh Pressure Metamorphism (R. Coleman and X. Wang, editors). Cambridge University Press, Cambridge MA.

Steiger, R.H. and Jäger, E. (1977) Subcommission on geochronology: convention on the use of decay constants in geo- and cosmochronology. Earth and Planetary Science Letters, 46, 359-362.

Stöckhert, B., Duyster, J., Trepmann, C. and Massonne H.-J. (2001) Microdiamond daughter crystals precipitated from supercritical $\mathrm{COH}$ silicate fluids included in garnet, Erzgebirge, Germany. Geology, 29, 391-394.

Tichomirowa, M., Berger, H.-J., Koch, E.A., Belyatski, B.V., Goetze, J., Kempe, U., Nasdala, L. and Schaltegger, U. (2001) Zircon ages of high-grade gneisses in the Eastern Erzgebirge (Central European Variscides) - constraints on origin of the rocks and Precambrian to Ordovician magmatic events in the Variscan foldbelt. Lithos, 56, 303-332.

Tichomirowa, M., Whitehouse, M.J. and Nasdala, L. (2005) Resorption, growth, solid state recrystallisation, and annealing of granulite facies zircon - a case study from the Central Erzgebirge, Bohemian Massif. Lithos, 82, 25-50.

Werner, O. and Reich, S. (1997) ${ }^{40} \mathrm{Ar} /{ }^{39} \mathrm{Ar}$-Abkühlalter von Gesteinen mit unterschiedlicher P-TEntwicklung aus dem Schiefermantel des Sächsischen Granulitgebirges. Terra Nostra, 97/5, 196-198.

Werner, O. and Lippolt, H.J. (2000) White mica ${ }^{40} \mathrm{Ar} /{ }^{39} \mathrm{Ar}$ ages of Erzgebirge metamorphic rocks: simulating the chronological results by a model of Variscan crustal imbrication. Pp. 323-336 in: Orogenic Processes: Quantification and Modelling in the Variscan Belt (W. Franke, V. Haak, O. Oncken and D. Tanner, editors). Special Publications, 179. Geological Society, London.

Willner, A.P., Rötzler, K. and Maresch, W.V. (1997) Pressure-temperature and fluid evolution of quartzofeldspathic metamorphic rocks with a relic highpressure, granulite-facies history from the Central Erzgebirge (Saxony, Germany). Journal of Petrology, 38, 307-336.

Willner, A.P., Krohe, A. and Maresch, W.V. (2000) Interrelated P-T-t-d paths in the Variscan Erzgebirge dome (Saxony, Germany): Constraints on the rapid exhumation of high-pressure rocks from the root zone of a collisional orogen. International Geology Review, 42, 64-85. 